\title{
Impact of spatial factors on climate variables and species distribution in forest ecosystems under sea influence of Eastern Black Sea Region, NE Turkey
}

\author{
Ayhan Usta ${ }^{1}$, Murat Yılmaz ${ }^{*}$, Yavuz Okunur Kocamanoğlu ${ }^{1}$, Esengül Genç ${ }^{1}$ \\ ${ }^{1, *}{ }^{*}$ Faculty of Forestry, Karadeniz Technical University, 61080 Trabzon, Turkey \\ Corresponding author:yilmaz61@ktu.edu.tr
}

\begin{abstract}
The distribution and characteristics of forest ecosystems are largely under the influence of climate. Climate directly affects the growth, leaf area and form, fenology and plant life, from seed to seedling formation. Climate varies from global scale to regional and local scales. Climate also has feedback mechanisms that can revert the changing vegetation back to its original state, through the changes it can create on vegetation. In this study, it was aimed to investigate the relationships between the distribution of tree species in the highland which is under the influence of the sea in Canik-Giresun Mountains, Trabzon Mountains and Rize-Kaçkar Mountains sites in the Eastern Black Sea Region, and spatial factors (altitude, distance from sea and latitude) and climate variables. The climate data, such as precipitation, temperature (average, minimum and maximum) and number of foggy days, of meteorological stations at different altitudes in coastal and mountainous areas under the influence of the sea were used in the study. $100 \mathrm{~m}$ increase in altitude led to a decrease in $26.9 \mathrm{~mm}$ precipitation in the Canik-Giresun Mountains, a decrease in $87.0 \mathrm{~mm}$ precipitation in the Rize-Kaçkar Mountains, and an average temperature decrease of $0.4^{\circ} \mathrm{C}$ in sites. The decrease in annual precipitations reaches $70 \mathrm{~mm}$ in Trabzon Mountains, $100 \mathrm{~mm}$ in Canik-Giresun Mountains and $290 \mathrm{~mm}$ in Rize-Kaçkar Mountains at a distance of $10 \mathrm{~km}$ away from the coast. Statistical increases were determined in the number of foggy days depending on the altitude and distance from the sea.

In the research area, at $3^{\text {rd }}$ altitude step where the distance from the sea and altitude are extreme, Scots pine, Oriental Spruce and Fir are spread in Canik-Giresun Mountains, Oriental Spruce and Scots pine are spread in Trabzon Mountains, and Oriental Spruce, Oriental Beech and Fir are spread in Rize-Kaçkar Mountains. Despite the decreasing amount of precipitation along with the increase in altitude and distance from the sea, the fog cloud in high mountainous areas plays an important ecological role in the conservation and distribution of these species.
\end{abstract}

Key words: Sites, altitude, latitude, distance from the sea, precipitation, temperature

\section{Özet}

Orman ekosistemlerinin dağılımı ve özellikleri büyük ölçüde iklimin etkisi altındadır. İklim, tohumdan fidan teşekkülüne, büyümeyi, yaprak alanı ve formunu, fenolojiyi ve bitki hayatını doğrudan etkiler. İklim, küresel ölçekten bölgesel ve yerel ölçeğe farklılık gösterir. İklimin, vejetasyon üzerinde meydana getirebileceği değişiklikler yoluyla, değişen vejetasyonu tekrar orijinal haline döndürebilecek geri besleme mekanizmaları da vardır. Bu çalışmada, Doğu Karadeniz Bölümü'nde Canik-Giresun Dağları, Trabzon Dağları ve Rize-Kaçkar Dağları yetişme ortamlarında deniz etkisi altındaki dağlık arazide ağaç türlerinin yayılışı ile konum faktörleri (yükselti, denizden uzaklık, enlem) ve iklim değişkenleri arasındaki ilişkilerin araştııllması amaçlanmıştır. Çalı̧̧ada, deniz etkisi altında kıyı ve dağlık alanlarda farklı yükseltilerdeki meteoroloji istasyonlarının yağış, sıcaklık (ortalama, minimum ve maksimum) ve sisli günler sayısı gibi iklim verilerinden yararlanılmıştır. 
Yükseltideki 100 m artış Canik-Giresun Dağları'nda 26.9 mm, Rize-Kaçkar Dağlarında 87.0 mm yağışta düşüşe; yetişme ortamlarında ortalama olarak $0.4^{\circ} \mathrm{C}$ ortalama sıcaklık düşüşüne sebep olmuştur. Yıllık yağışlardaki düşüş, sahilden 10 km uzaklaşıldığında, Trabzon Dağları'nda 70 mm, Canik-Giresun Dağlarında 100 mm ve Rize-Kaçkar Dağlarında 290 mm'ye ulaşmaktadır. Yükselti ve denizden uzaklığa bağlı olarak sisli gün sayısında istatistiksel olarak artışlar belirlenmiştir.

Araştırma alanında, denizden uzaklığın ve yükseltinin ekstrem olduğu III. yükselti basamağında, Canik-Giresun dağlarında Sarıçam, Doğu Ladini ve Göknar, Trabzon dağlarında Doğu Ladini ve Sarıçam, Rize-Kaçkar Dağlarında Doğu Ladini, Doğu Kayını ve Göknar yayılış göstermektedir. Yükselti ve denizden uzaklığın artması ile düşen yağış miktarına rağmen, yüksek dağlık alanlardaki sis bulutu bu türlerin korunmasında ve yayılışında önemli ekolojik bir rol üstlenmektedir.

Anahtar kelimeler: Yetişme ortamları, yükselti, enlem, denizden uzaklık, yağış, sıcaklık

\section{Introduction}

There are many different factors that affect the climate of a place in the world. The climate of a region is determined by the interaction of some important natural controls such as latitude (proximity to the equator), altitude, distance from the sea, aspect, slope, ocean currents, orographic effect, warming and cooling characteristics and air pressure. It has been recently accepted that human activity also affects the climate (Scott, 2004). The changes in altitude may cause big differences in temperature even at similar latitudes. For this reason, high mountain and plateau stations are much colder than the lowaltitude stations at the same latitude (Apaydın et al., 2011). In many parts of the world, mountains are open to the effects of a rapidly changing climate and are interesting places for early detection and analysis of the signals of climate change and their effects on hydrological, ecological and social systems (Beniston, 2005). Although the mountains are very different from region to region, their common characteristic is the complexity of their topography. Orographic characteristics affect the rapid and systematic changes especially in temperature and precipitation conditions at very short distances in climate parameters (Becker and Bugmann, 1997; Arnbjerg-Nielsen et al., 2013), directly developing flow and erosion, the systematic change of other climate variables (e.g., radiation), and the environmental factors (such as the differences in soil types). Orographic effect is the lifting effect on winds passing over the mountain peaks or ranges. The air rises as it approaches a mountain barrier, and it typically generates clouds and precipitation usually on the windward side of the mountains. The wettest parts of the world are located on the windward side of high mountain ranges (Clarke and Wallace, 1999; Jackson, 2000; Scott, 2004; Espinoza et al., 2015). These factors are the spatial functions, and the accurate determination of spatial distribution of meteorological variables is as important as their measurements (Apaydin et al., 2004).

The climate factors, such as temperature, potential evapotranspiration, growing season length, moisture, air pressure, presence of nutrients, ultraviolet radiation and precipitation, vary depending on the altitude (Funnell \& Parish, 2001). The range of change of tree species spreading in this change is determined directly or indirectly by the inappropriate extremes of these climate factors. The upper limit of the distribution of a species can be determined by a combination of climate and biotic factors (MacArthur, 1972; Ehrlén and Morris, 2015). For this reason, the distribution and characteristics of forest ecosystems are largely controlled by climate. At the individual level, climate directly affects the reproduction of seeds and seedling formation (Renard et al. 2016), the growth (Carrer \& Urbinati, 2004, 2006), the leaf area and form (Fisher et al. 2007; Yang et al., 2015), the fenology (Petrotelli et al. 2005), and the lifespan of the plant as an individual (Goulden et al., 1998). The influence of climate in nature varies from global scale to regional and local scales. Climate also has feedback mechanisms that can revert the changing vegetation back to its original state, through the changes it can create on vegetation (Bonan et al. 1992; Lynch et al., 1999; Anderson-Teixeira et al. 2013).

In this study, it was aimed to reveal the relationships between the spatial factors affecting the distribution of forest-building tree species in the highland which is under the influence of the sea in the 
sub-regional sites in the Eastern Black Sea Region and climate variables. For this purpose, the statistical relationships between spatial factors (altitude, latitude and distance from the sea) in the highland under the influence of the sea and the climate variables were investigated, the distribution of spreading tree types was evaluated according to spatial factors.

\section{Methods}

\section{Study Area}

This study was carried out in the ecological units which are under the influence of the sea of Ordu, Giresun, Trabzon, Rize and Artvin provinces that are geographically located in the Eastern Black Sea Region of the Black Sea Region. The sub-regional sites formed by Kantarc1 (1995) in the "Site under the influence of the sea", based on the earth-climate relationship for the Eastern Black Sea Region were taken into account while determining the study area. These site regions are Canik-Giresun Mountains, Trabzon Mountains and Rize-Kaçkar Mountains (Figure 1).

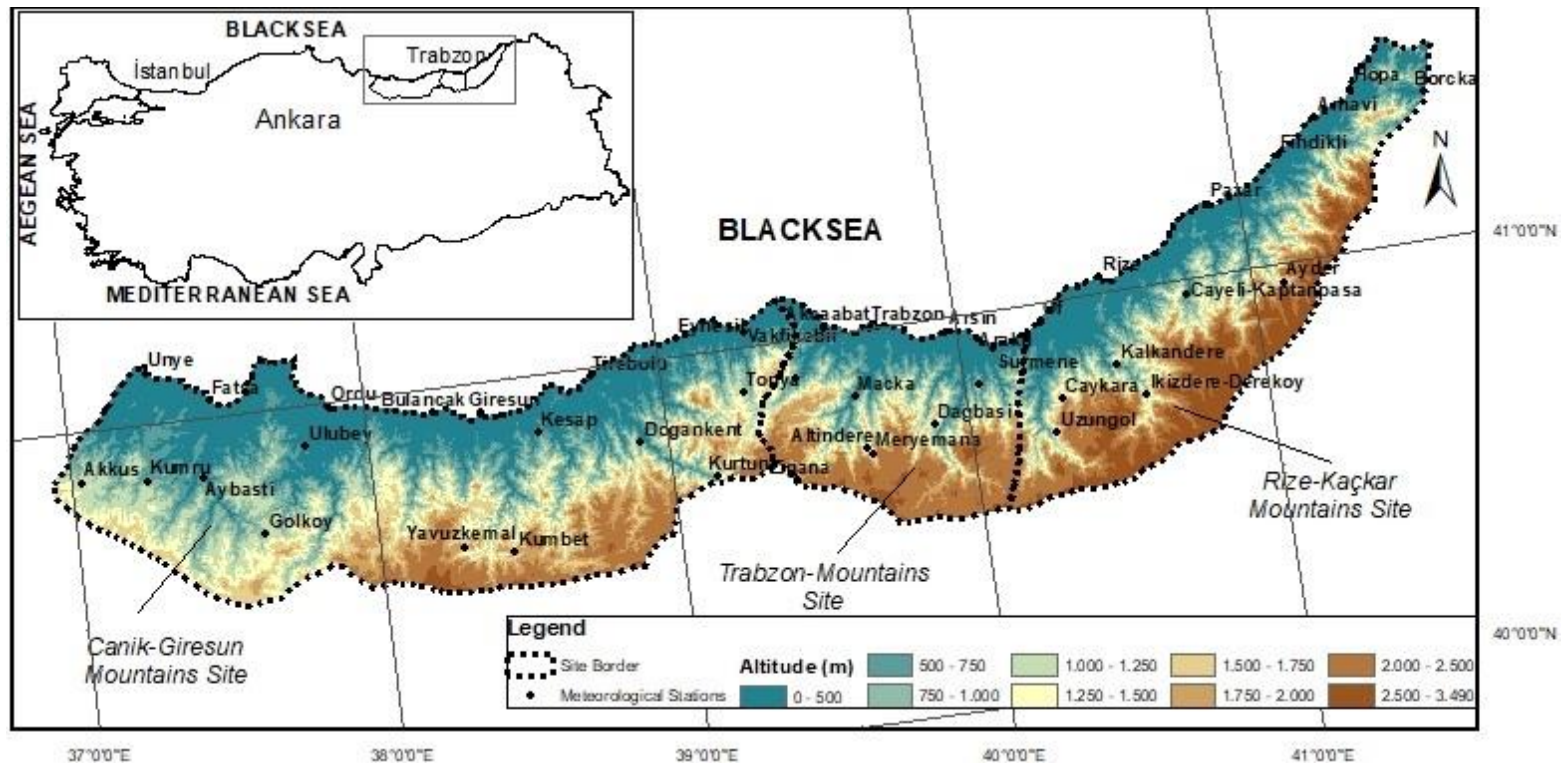

Figure 1. Location of the study area and DEM map

The study area is located between $40^{\circ} 30^{\prime} 42^{\prime \prime} \mathrm{N}-41^{\circ} 31^{\prime} 2 " \mathrm{~N}$ latitudes and $36^{\circ} 56^{\prime} 11^{\prime \prime} \mathrm{E}-41^{\circ} 43^{\prime} 11^{\prime \prime} \mathrm{E}$ longitudes. In the site which is under the influence of the sea, Canik-Giresun Mountains cover an area of $10149.54 \mathrm{~km}^{2}$, Trabzon Mountains cover an area of $3362.49 \mathrm{~km}^{2}$, and Rize-Kaçkar Mountains cover an area of $5869.24 \mathrm{~km}^{2}$. The study area is a total of $19381,27 \mathrm{~km}^{2}$.

The study area is located within A6-A8 squares of the Euro-Siberian floristic region among 3 floristic regions identified for Turkey. Euro-Siberian region is represented by Auxin province in Turkey. This site extends to the western part of the Caucasus, involving the whole northern Anatolia. A leafy forest formation merged with coniferous species at higher altitudes spreads in the Auxin province. In the auxin vegetation areas, there is no significant summer drought due to summer rains. The annual amount of precipitation exceeds $1000 \mathrm{~mm}$ in many places (Davis, 1971).

\section{Climate Data}

The data of meteorological stations (annual precipitation, average temperature, minimum temperature, maximum temperature and number of foggy days) at different altitudes in coastal and mountainous areas under the influence of the sea were used in the study (TSMS, 2018). The data of a total of 44 
meteorological stations, including 19 meteorological stations in Canik-Giresun Mountains, 12 meteorological stations in Trabzon Mountains, and 13 meteorological stations in Rize-Kaçkar Mountains, were evaluated. The location information of meteorological stations (altitude, distance from the sea, latitude, longitude, years with data available) is presented in Table 1.

Table 1. Spatial features of the stations used in the study

\begin{tabular}{|c|c|c|c|c|c|}
\hline \multirow[b]{2}{*}{ Stations in Sites } & \multirow[b]{2}{*}{ Altitude (m) } & \multirow{2}{*}{$\begin{array}{l}\text { Distance From } \\
\text { Sea }(\mathrm{km})\end{array}$} & \multicolumn{2}{|c|}{ UTM } & \multirow{2}{*}{$\begin{array}{c}\text { Years with } \\
\text { data available }\end{array}$} \\
\hline & & & Latitude & Longitude & \\
\hline \multicolumn{6}{|c|}{ Canik-Giresun Mountains } \\
\hline Akkuş & 1190 & 38,305 & 346254 & 4573001 & 1989-1992 \\
\hline Aybastı & 640 & 21,433 & 380413 & 4574322 & 1986-1994 \\
\hline Gölköy & 925 & 44,948 & 398465 & 4558640 & $1986-1993$ \\
\hline Kumru & 600 & 30,738 & 364489 & 4573715 & 1986-1992 \\
\hline Ordu & 5 & 0,050 & 416568 & 4594601 & $1961-2016$ \\
\hline Ulubey & 400 & 13,016 & 409743 & 4583550 & $1986-1993$ \\
\hline Ünye & 16 & 0,284 & 363973 & 4604414 & $1986-2016$ \\
\hline Doğankent & 550 & 26,690 & 505472 & 4584678 & $1983-1993$ \\
\hline Giresun & 38 & 0,030 & 459753 & 4593188 & $1950-2015$ \\
\hline Kümbet Yaylası & 1730 & 43,356 & 469512 & 4553302 & $2010-2017$ \\
\hline Eynesil-Ören & 10 & 0,384 & 515286 & 4614125 & $1989-1993$ \\
\hline Tirebolu & 10 & 0,409 & 490870 & 4603605 & $1986-2000$ \\
\hline Yavuzkemal & 1711 & 50,184 & 455439 & 4554880 & $2012-2017$ \\
\hline Keşap-Yivdincik & 680 & 7,973 & 476306 & 4587419 & 2014-2017 \\
\hline Kürtün & 739 & 50,249 & 527504 & 4575167 & $1987-1993$ \\
\hline Tonya & 900 & 18,791 & 534633 & 4599003 & 1976-1995 \\
\hline Vakfikebir & 215 & 2,539 & 535044 & 4616071 & $1983-2010$ \\
\hline Fatsa & 2 & 0,144 & 382217 & 4596669 & 2010-2016 \\
\hline Bulancak & 10 & 0,020 & 446371 & 4593314 & $1965-1997$ \\
\hline \multicolumn{6}{|l|}{ Trabzon Mountains } \\
\hline Akcaabat & 3 & 0,991 & 557856 & 4617484 & $1963-2015$ \\
\hline Altindere & 1030 & 39,132 & 570275 & 4583113 & 2011-2015 \\
\hline Arsin & 10 & 0,378 & 592503 & 4616168 & 1984-1995 \\
\hline Arakli & 10 & 0,158 & 601364 & 4614415 & $1983-1996$ \\
\hline Duzkoy & 850 & 17,910 & 549864 & 4603020 & $1986-2003$ \\
\hline Trabzon & 25 & 1,343 & 570784 & 4617511 & $1950-2015$ \\
\hline Zigana & 2050 & 51,281 & 550001 & 4573740 & $2010-2016$ \\
\hline Meryemana & 1100 & 41,209 & 571674 & 4581544 & $1976-1986$ \\
\hline Dagbasi & 1450 & 29,195 & 589221 & 4589929 & $1989-1998$ \\
\hline Macka & 265 & 22,037 & 566457 & 4597873 & 1964-1997 \\
\hline Kucukdere & 925 & 12,277 & 601969 & 4601252 & $1988-1993$ \\
\hline Sürmene & 50 & 1,602 & 606144 & 4611420 & $1989-1998$ \\
\hline \multicolumn{6}{|c|}{ Rize-Kaçkar Mountains } \\
\hline Of & 10 & 0,566 & 619393 & 4619186 & 1964-1994 \\
\hline Uzungöl & 1450 & 34,059 & 624271 & 4587560 & $1983-2015$ \\
\hline Caykara & 800 & 22,404 & 625690 & 4597284 & $1989-1998$ \\
\hline Ayder & 1354 & 33,173 & 689214 & 4630480 & $2010-2016$ \\
\hline Ikizdere-Derekoy & 800 & 39,811 & 650024 & 4598325 & $1970-1996$ \\
\hline Findikli & 190 & 1,004 & 687173 & 4666650 & $1989-2000$ \\
\hline Kalkandere & 400 & 26,854 & 641255 & 4606754 & $1986-1996$ \\
\hline Cayeli-Kaptanpasa & 525 & 16,703 & 661119 & 4626687 & $1965-1986$ \\
\hline Pazar & 78 & 0,472 & 667314 & 4652778 & $1963-2015$ \\
\hline Rize & 3 & 0,050 & 636236 & 4632061 & $1950-2015$ \\
\hline Arhavi & 10 & 0,071 & 697598 & 4677430 & $1983-1993$ \\
\hline Borcka & 120 & 21,893 & 728786 & 4684658 & $1987-2003$ \\
\hline Hopa & 33 & 0,267 & 707918 & 4685750 & $1962-2015$ \\
\hline
\end{tabular}

In the separation performed by Kantarc1 (1995) to determine site regions for the Eastern Black Sea Region, the areas where there are Of, Çaykara and Uzungöl meteorological stations were shown in the Trabzon Mountains site. However, these areas were shifted to Rize-Kaçkar Mountains due to a transition climate between Trabzon Mountains and Rize-Kaçkar Mountains and high amount of annual precipitation (Table 1).

\section{Determination of spatial factors and species distribution in forest sites}

In the separation based on the relationship between earth shape and climate, Kantarc1 (1995) separated a total of 6 sub-regional sites within two sites in the eastern black sea geography and stated that the 
boundaries of regional classification complied with the boundaries of forest managements. In the study, the data of the General Directorate of Forestry were used for the distribution of forest trees spreading in the site under the influence of the sea (GDF, 2008; GDF, 2012; GDF, 2015). In the distribution of forest trees, the areas covered by dominant species in normal, degraded and very degraded forest sites were taken into account.

ArcGis/Arcmap software was used in determining the spatial features (slope, aspect, altitude, longitude, distance from the sea) of sites. SRTM 1 Version 3 (Shuttle Radar Topography Mission) satellite data at $30 \mathrm{~m}$ resolution with open access were used to obtain the digital elevation model (DEM), which is one of the inputs required for GIS analysis. By performing improvement and updating studies on SRTM data, they are presented with an increased sensitivity at $30 \mathrm{~m}$ resolution ( $\mathrm{Li}$ et al. 2012, Mohd et al. 2014). The altitude, slope and aspect of site regions were generated using the SRTM data. According to the data obtained from the digital elevation model of the study area, the altitude was represented in 3 groups $(0-1000 \mathrm{~m}, 1000-2000 \mathrm{~m}$ and $2000-\mathrm{m})$ and \% slope was represented in 5 groups $(0-20,20-$ $40,40-60,60-80$ and $80<$ ). Furthermore, the systematic points on the study area (representing about $17 \mathrm{ha}$ ) were removed to determine the relationship between altitude and distance from the sea.

\section{Statistical Analysis}

In the study, the relationships between spatial factors (altitude, distance from sea and latitude) and climate parameters (precipitation, average temperature, minimum temperature, maximum temperature, number of foggy days) in forest ecosystemss were investigated. Regression analysis was used in the prediction of precipitation and average temperature in conjunction with the altitude and distance from the sea in forest ecosystemss. All statistical analyses were performed in the SPSS program.

\section{Results}

\section{Relationships between climate parameters and spatial factors}

The relationship between spatial factors of the selected meteorological stations and climate parameters was determined by correlation analysis. Significant and meaningful relationships were found between the spatial factors, like altitude, distance from the sea and latitude in sites, and meteorological parameters (Table 2).

Table 2. Correlation coefficients between climate parameters and spatial factors in the sites

\begin{tabular}{|c|c|c|c|c|c|}
\hline \multirow{2}{*}{ Spatial Factors } & \multicolumn{5}{|c|}{ Climate Parameters } \\
\hline & Precipitation & Average Temp. & Min. Temp. & Max. Temp. & Foggy Days \\
\hline \multicolumn{6}{|c|}{ Canik-Giresun Mountains } \\
\hline Altitude &,$- 621^{* *}$ &,$- 930^{* *}$ &,$- 893^{* *}$ &,$- 917^{* *}$ &, $871^{* *}$ \\
\hline Distance from sea &,$- 666^{* *}$ &,$- 884^{* *}$ &,$- 908^{* *}$ &,$- 781^{* *}$ & $636^{* *}$ \\
\hline Latitude &, $562^{* *}$ &, $861^{*}$ &, $874^{*}$ &, $782^{*}$ &,$- 749^{*}$ \\
\hline \multicolumn{6}{|l|}{ Trabzon Mountains } \\
\hline Altitude &,- 521 &,$- 767^{* *}$ &,$- 909^{* *}$ &,$- 705^{* *}$ &, $805^{* *}$ \\
\hline Distance from sea &,$- 622^{*}$ &,$- 742^{*}$ &,$- 970^{* *}$ &,$- 754^{*}$ & $763^{* *}$ \\
\hline Latitude &, $642^{*}$ &, $897^{* * *}$ &, $871^{*}$ &, $782^{*}$ &,$- 749^{*}$ \\
\hline \multicolumn{6}{|l|}{ Rize-Kaçkar Mountains } \\
\hline Altitude &,$- 812^{* *}$ &,$- 951^{* *}$ &,$- 878^{* *}$ &,$- 896^{* *}$ &, $852^{* *}$ \\
\hline Distance from sea &,$- 798^{* *}$ &,$- 769^{* *}$ &,$- 724^{* *}$ &,$- 629^{*}$ &, 570 \\
\hline Latitude &, $542^{*}$ & ,408 & ,357 & ,381 &,- 368 \\
\hline
\end{tabular}

* Significance at 0.05 probability level.

** Significance at 0.01 probability level

In Canik-Giresun and Rize-Kaçkar Mountains, altitude showed a negative correlation on other climate parameters except for the numbers of foggy days (Table 2). In Trabzon Mountains, altitude once again showed a negative correlation on average minimum and maximum temperatures except for the numbers 
of foggy days; however, no correlation was found between precipitation and altitude. This shows that the precipitation, average temperature, minimum and maximum temperature parameters decreased along with the increase in altitude in Canik-Giresun and Rize-Kaçkar Mountains, and the number of foggy days increased. In Trabzon Mountains, increase in altitude did not affect precipitation, decreased the average temperature, minimum and maximum temperatures but increased the number of foggy days. The degree of latitude had a similar effect in Canik-Giresun and Trabzon Mountains. The increase in latitude increased the precipitation, average temperature, minimum and maximum temperatures and decreased the numbers of foggy days (Table 2). The increase in the degree of latitude in Rize-Kaçkar Mountains led to an increase in precipitation and a decrease in the number of foggy days. Canik-Giresun Mountains are located between $41^{\circ} 6^{\prime} \mathrm{N}-40^{\circ} 30^{\prime} \mathrm{N}$ latitudes, Trabzon Mountains are located between $41^{\circ} 6^{\prime} \mathrm{N}-40^{\circ} 29^{\prime} \mathrm{N}$ latitudes and Rize-Kaçkar Mountains are located between $41^{\circ} 31^{\prime} \mathrm{N}-40^{\circ} 29^{\prime} \mathrm{N}$ latitudes (Figure 1). Canik-Giresun and Trabzon Mountains are located between approximately same latitudes while Rize-Kaçkar Mountains are located in the further north.

The distance from the sea showed a similar effect to altitude in all sites except for the number of foggy days in Rize-Kaçkar Mountains. However, the distance from the sea in Trabzon Mountains showed a negative correlation on precipitation. Within the scope of the study, regression analysis was performed since a positive correlation was found between altitude and distance from the sea in sites (Table 3 ). The relationship between altitude and distance from the sea is presented in Figure 2.

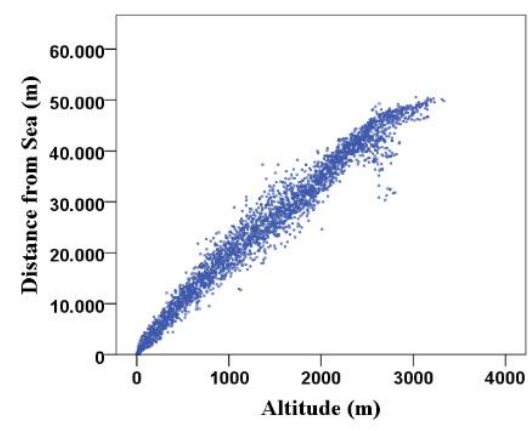

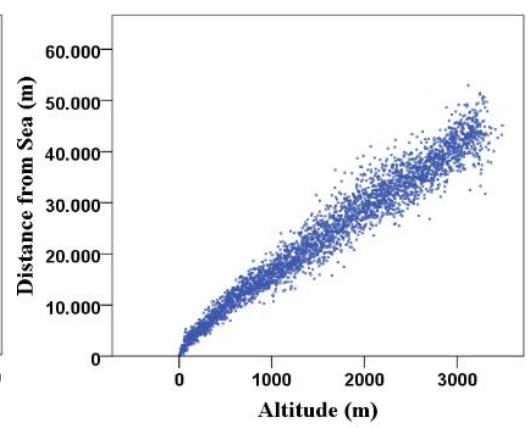

$\mathrm{b}$

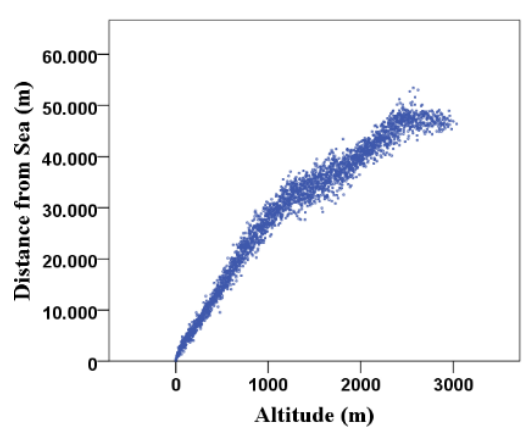

c

Figure 2. Relationship between altitude and distance from the sea

As a result of the regression analysis performed for the estimation of altitude based on distance from the sea, equations were revealed for each of sites (Table 3). Accordingly, the increase in altitude due to distance from the sea is the highest in Rize-Kaçkar Mountains. For instance, at a distance of $50 \mathrm{~km}$ away from the coast, an altitude of $1957.55 \mathrm{~m}$ is reached in Canik-Giresun Mountains, an altitude of 2619.45 $\mathrm{m}$ is reached in Trabzon Mountains, and an altitude of $3182.17 \mathrm{~m}$ is reached in Rize-Kaçkar Mountains.

Table 3. Stepwise multiple regression models for altitude and distance from the sea in the sites

\begin{tabular}{lcccccc}
\hline \multicolumn{1}{c}{ Forest Sites } & Min & Max & Mean & Regression Equations & $\mathrm{R}^{2}$ & Adjusted R \\
\hline $\begin{array}{l}\text { Canik-Giresun Mountains } \\
\text { Altitude }\end{array}$ & 107.55 & 2191.22 & 1004.16 & $107.553+0.037 * \mathrm{DFS}(\mathrm{m})$ & 0.688 & 0.668 \\
\hline $\begin{array}{l}\text { Trabzon Mountains } \\
\text { Altitude }\end{array}$ & 119.48 & 2738.72 & 1370.67 & $119.451+0.050 * \mathrm{DFS}(\mathrm{m})$ & 0.815 & 0.805 \\
\hline $\begin{array}{l}\text { Rize-Kaçkar Mountains } \\
\text { Altitude }\end{array}$ & 82.18 & 3378.50 & 1352.25 & $82.168+0.062 * \mathrm{DFS}(\mathrm{m})$ & 0.800 & 0.780 \\
\hline
\end{tabular}

Regression analyses were performed for the estimation of precipitation and average temperature based on altitude and distance from the sea in site regions (Table 4). 
Table 4. Stepwise multiple regression models for some spatial factors and climate parameters in the sites

\begin{tabular}{|c|c|c|c|c|c|c|}
\hline Climate Parameters & Min & Max & Mean & Regression Equations & $\mathrm{R}^{2}$ & Adjusted $\mathrm{R}^{2}$ \\
\hline \multicolumn{7}{|l|}{ Canik-Giresun Mountains } \\
\hline Precipitation & 606.60 & 1568.20 & 1041.62 & 1175.413-0.269*ALT (m) & 0.386 & 0.352 \\
\hline Average Temperature & 5.80 & 15.50 & 11.55 & $14.317-0.005^{*}$ ALT (m) & 0.866 & 0.858 \\
\hline \multicolumn{7}{|l|}{ Trabzon Mountains } \\
\hline Precipitation & 522.90 & 1226.50 & 785.88 & $07 * \operatorname{DFS}(\mathrm{m})$ & 0.396 & 0.336 \\
\hline Average Temperature & 4.40 & 14.90 & 12.17 & $14.543-0.003 *$ ALT $(\mathrm{m})$ & 0.588 & 0.536 \\
\hline \multicolumn{7}{|l|}{ Rize-Kaçkar Mountains } \\
\hline Precipitation & 817.80 & 2327.40 & 1606.17 & 1981.34-0.870*ALT (m) & 0.659 & 0.630 \\
\hline Average Temperature & 8.30 & 14.60 & 12.33 & $14.020-0.004 *$ ALT (m) & 0.904 & 0.896 \\
\hline
\end{tabular}

In the study, it was observed that precipitation decreased in Canik-Giresun and Rize-Kaçkar Mountains depending on the altitude in the site under the influence of the sea. The decrease in annual precipitation at an altitude of $100 \mathrm{~m}$ was $26.9 \mathrm{~mm}$ and $87.0 \mathrm{~mm}$ in Canik-Giresun Mountains and Rize-Kaçkar Mountains, respectively. The decrease in average temperatures due to altitude was found to be close in sites. The decrease in average temperature in sites was $0.3-0.5^{\circ} \mathrm{C}$ at an altitude of $100 \mathrm{~m}$. Decreases were observed in annual precipitation due to distance from the sea. At a distance of $10 \mathrm{~km}$ away from the coast, the decrease in average annual total precipitation was $100 \mathrm{~mm}$ in Canik-Giresun Mountains, $70 \mathrm{~mm}$ in Trabzon Mountains and $330 \mathrm{~mm}$ in Rize-Kaçkar Mountains.

\section{Relationships between spatial factors, climate and species distributions in forest sites}

It was determined that the average slope was 23\% in Canik-Giresun Mountains, 28\% in Trabzon Mountains and 32\% in Rize-Kaçkar Mountains. The average altitude is $994 \mathrm{~m}$ (max. $3037 \mathrm{~m}$ ) in CanikGiresun Mountains, 1319 m (max. 3002 m) in Trabzon Mountains and 1389 m (max. 3490 m) in RizeKaçkar Mountains (Figure 1). The slope and altitude increase as going from west to east in sites. In the Eastern Black Sea region, the forest-building tree species in the sub-regional sites are Oriental Beech, Oriental Spruce, Scots pine, Alder, Chestnut, Hornbeam, Fir and Oak. The species involved in mixture with very low quantities were excluded from the study (Figure 3).

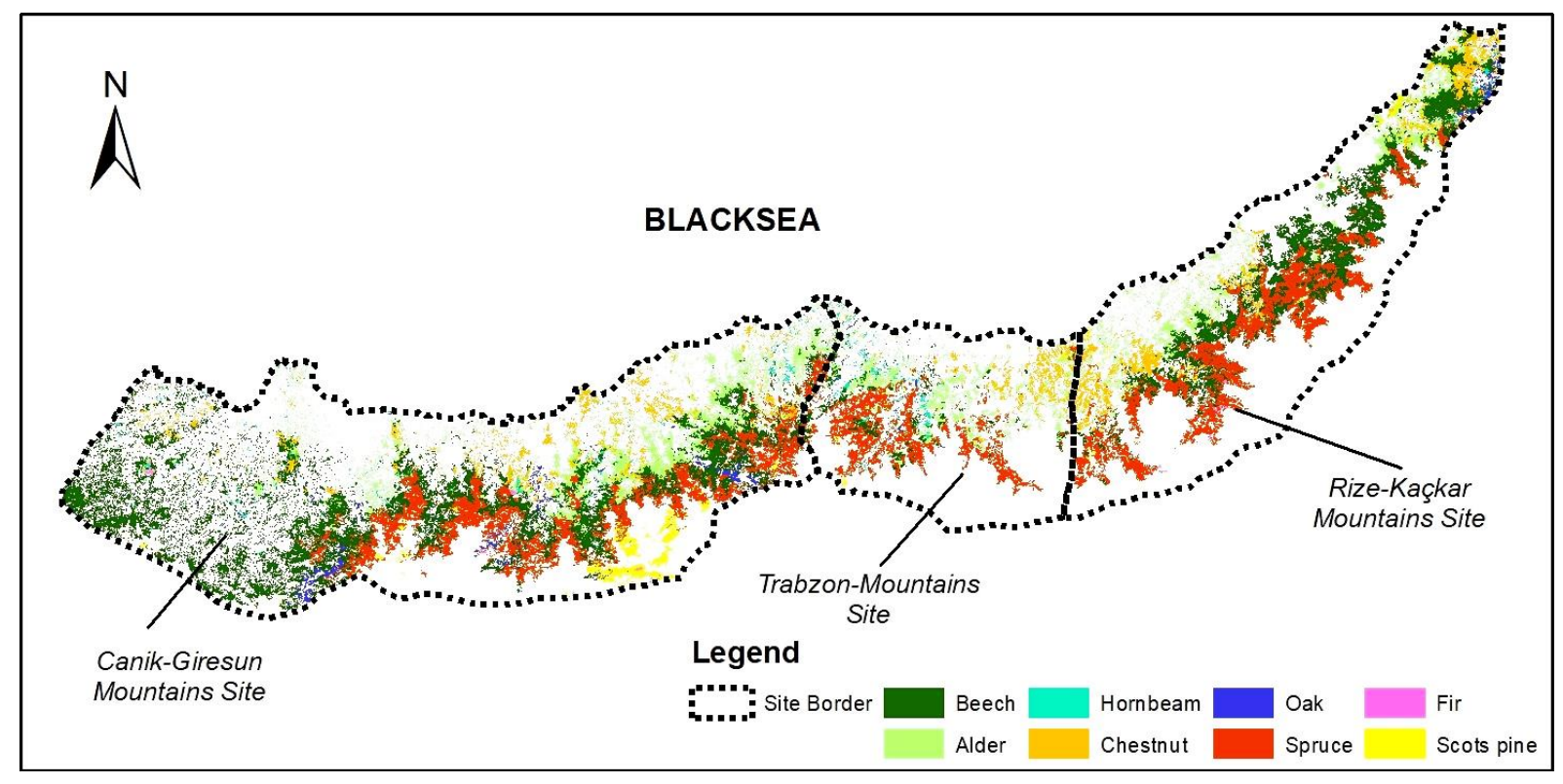

Figure 3. Distribution map of the dominant tree species in Eastern Black Sea region 
The areal (\%) distributions of forest-building tree species in the forest sites according to altitude steps and aspect groups are given below (Figure 4-6). Oriental Beech is the dominant species in both aspect groups at $0-1000 \mathrm{~m}\left(1^{\text {st }}\right.$ altitude step $)$ and $1000-2000 \mathrm{~m}$ ( $2^{\text {nd }}$ altitude step $)$ altitude steps in the CanikGiresun Mountains site. Oriental Beech is followed by Alder at $1^{\text {st }}$ altitude step and Oriental Spruce at $2^{\text {nd }}$ altitude step. At $3^{\text {rd }}$ altitude step, Scots pine is the dominant species in both aspects. Scots pine is followed by Oriental Spruce (Figure 4).

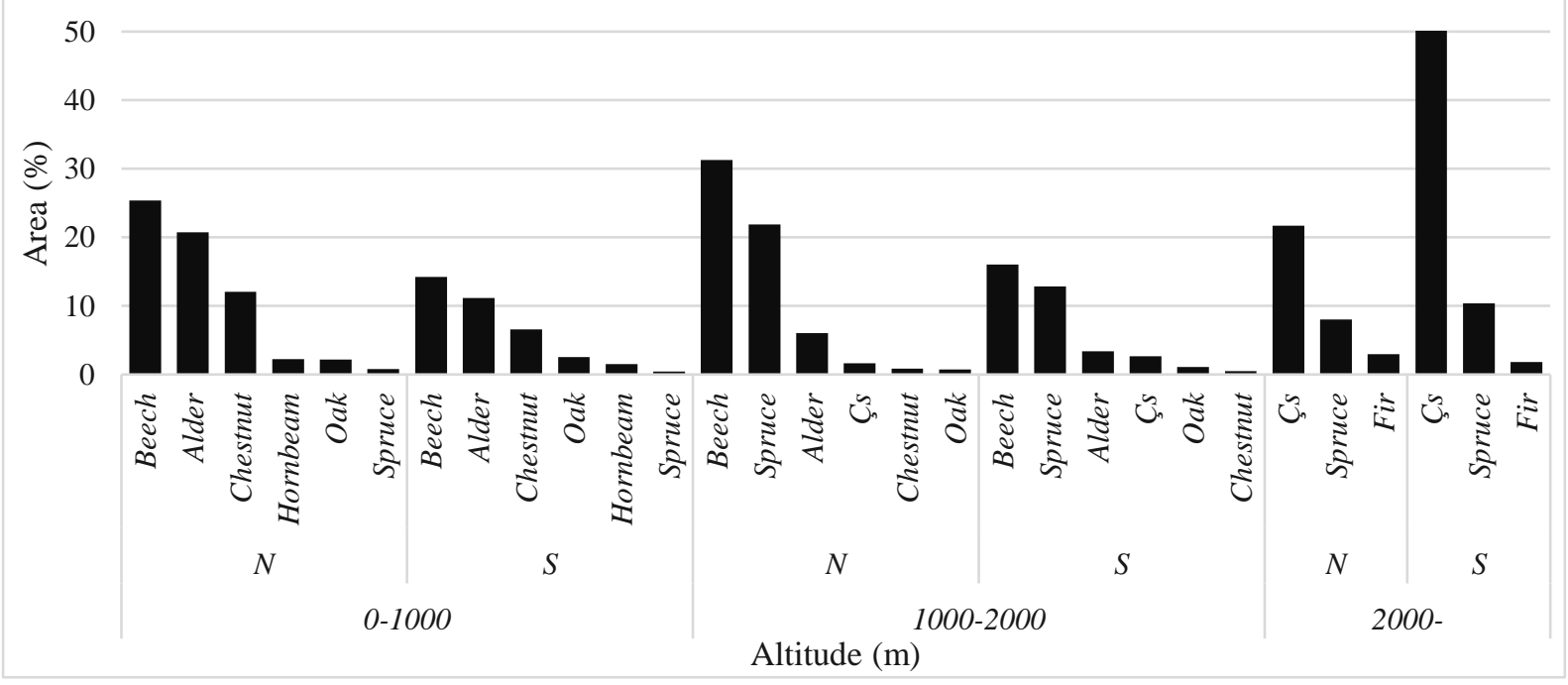

Figure 4. Distribution of dominant tree species in Canik-Giresun Mountains by altitude and aspect

In Trabzon Mountains site, Alder is dominant at $1^{\text {st }}$ altitude step and Oriental Spruce is dominant at $2^{\text {nd }}$ altitude step in both aspect groups. Alder and Oriental Spruce are followed by Chestnut and Alder, respectively. At $3^{\text {rd }}$ altitude step, Oriental Spruce is the dominant species in both aspects. Oriental Spruce is followed by Scots pine (Figure 5).

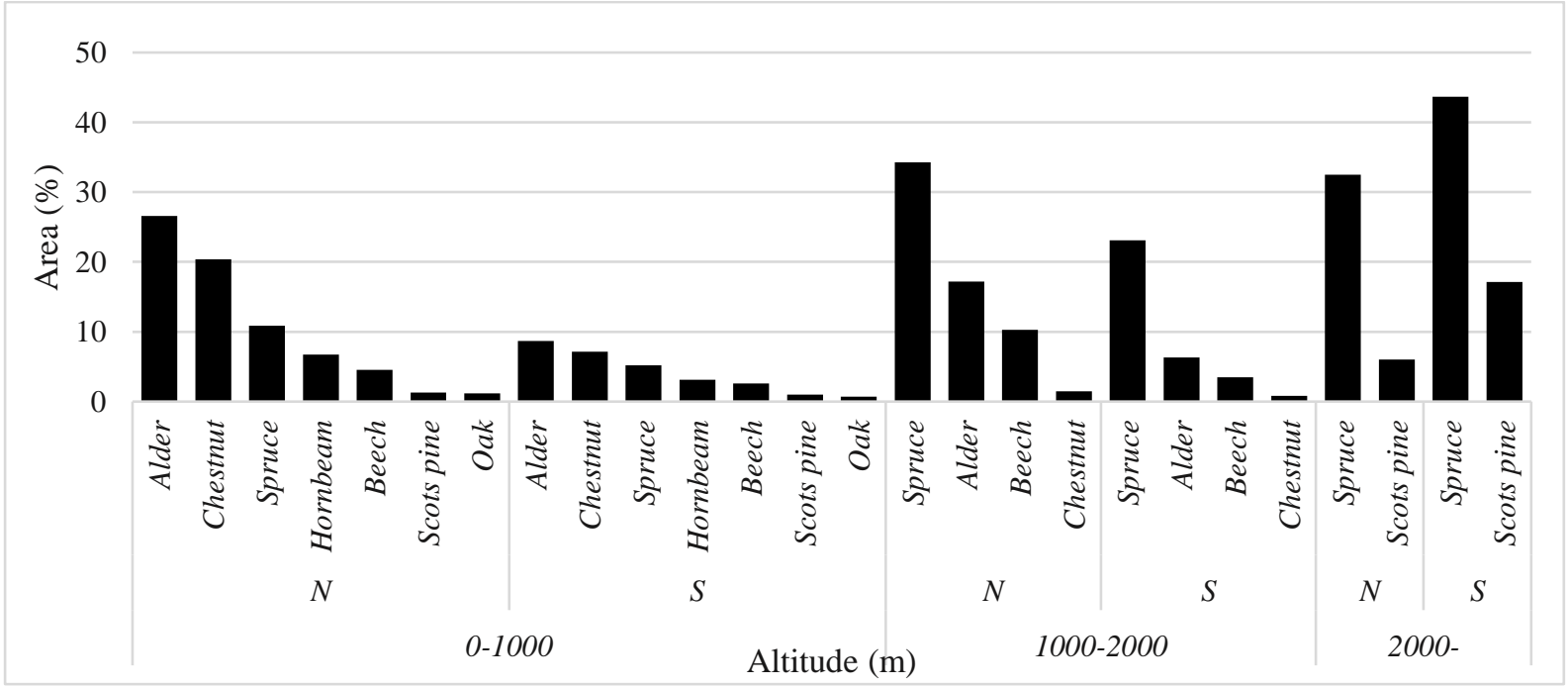

Figure 5. Distribution of dominant tree species in Trabzon Mountains by altitude and aspect

In Rize-Kaçkar Mountains site, Alder is the dominant species at $1^{\text {st }}$ altitude step in both aspect groups. Alder is followed by Oriental Beech. At $2^{\text {nd }}$ and $3^{\text {rd }}$ altitude steps, Oriental Spruce is the dominant species in both aspect groups. Oriental Spruce is followed by Alder at $2^{\text {nd }}$ altitude step and Scots pine at $3^{\text {rd }}$ altitude step (Figure 6). 


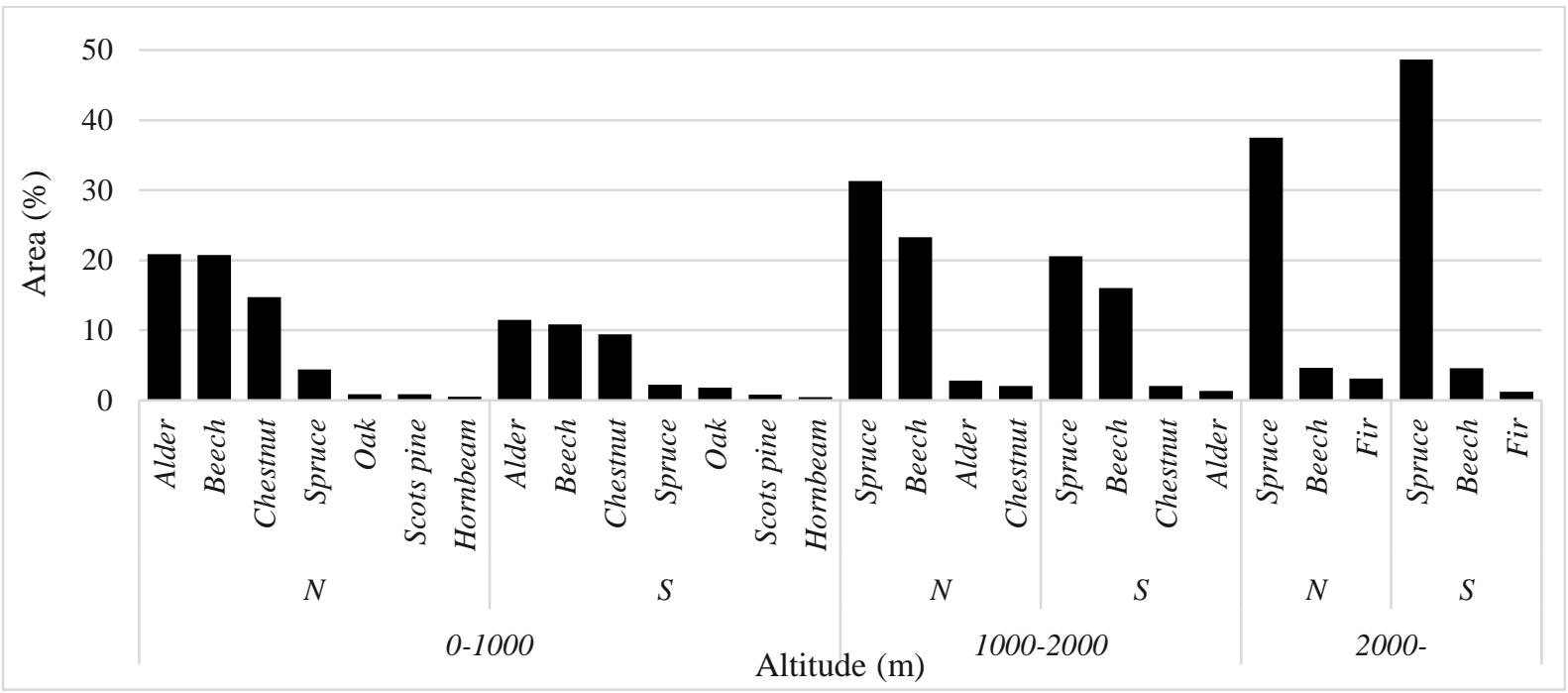

Figure 6. Distribution of dominant tree species in Rize-Kaçkar Mountains by altitude and aspect

When all site regions are evaluated, it is seen that the forest-building tree species at $1^{\text {st }}$ and $2^{\text {nd }}$ altitude steps are mainly present in the North aspect by area (\%). However, the South aspect group gets this superiority at $3^{\text {rd }}$ altitude step. Scots pine is the dominant species in Canik-Giresun Mountains and Oriental Spruce is the dominant species in Trabzon and Rize-Kaçkar Mountains. Scots pine is followed by Oriental Spruce in Canik-Giresun Mountains, Oriental Spruce is followed by Scots pine in Trabzon Mountains, and Oriental Spruce is followed by Oriental Beech in Rize-Kaçkar Mountains. At $3^{\text {rd }}$ altitude step in Rize-Kaçkar Mountains, Oriental Spruce is apparently dominant while Oriental Beech is at much lower rates. While the distribution of species in the north aspect is more dominant at $1^{\text {st }}$ and $2^{\text {nd }}$ altitude steps, it is interesting that the south aspect group gets the dominance at $3^{\text {rd }}$ altitude step. When it is noted, Scots pine and Oriental Spruce are more dominant in the south aspect group. It would not be wrong to say that the light demands of tree species come to the forefront at this altitude $(2000 \mathrm{~m}<)$ where the vegetation period is quite shortened. Indeed, the light demands of Scots pine and Oriental Sprucen are higher compared to Oriental Beech and Fir.

\section{Discussion}

\section{Relationships between climate parameters and spatial factors}

The Eastern Black Sea Mountains constitute the highest part of the mountain range that surrounds our country from the north. The mountain range starts to rise as going from Central Black Sea Region to the east and reaches the highest level in Kaçkar Mountains. The mountain range with an extension in the east-west direction in Central Black Sea Region changes the direction as going towards the east and has an extension in the southwest-northeast direction. In this section, Eastern Black Sea Mountains rise suddenly at the backshore and exceed 3000 meters at a distance of about 20-30 km (Çiçek et al. 2003). The effects of topographic factors such as altitude, slope status, orographic mountain ranges and continentality play the most significant role in the classification of habitats and ecosystems. For instance, local climate changes, and the distribution of vegetation cover both at vertical and horizontal distances are controlled by topographic factors (Atalay, İ. et al. 1985).

In this study, in contrast to the studies in which precipitation in mountainous areas is stated to increase typically with altitude (Daly et al., 1994; Park and Singh, 1996; Sevruk, 1997; Marquinez et al., 2003; Naoum and Tsanis, 2004), precipitation decreased along with the increase in altitude in Canik-Giresun and Rize-Kaçkar Mountains sites, except for Trabzon Mountains (Table 2). This decrease corresponds 
to a decrease of $538 \mathrm{~mm}$ in Canik-Giresun Mountains and a decrease of $1740 \mathrm{~mm}$ in Rize-Kaçkar Mountains in the areas above $2000 \mathrm{~m}$. There is no statistically significant and meaningful relationship between altitude and precipitation in Trabzon Mountains (Table 2). The accumulation of humid air masses coming over the Black Sea in front of the high highland leads to a huge amount of precipitation on the coastline. The air with decreasing humidity that rises on mountain slopes and also becomes cold as it rises also enables the formation of precipitation in these parts (Kantarc1 1995). The accumulation of humid air in front of a barrier, its rise, cooling and condensation, and the formation of precipitation are more apparent in Taurus Mountains in the Mediterranean Region (Kantarc1 1982). Warm and humid air masses coming from the Mediterranean need to rise by $600-800 \mathrm{~m}$ on the slopes of the Taurus Mountains for their cooling and the condensation of the moisture they contain. Since the winds coming from the Black Sea are cooler, they can be cooled at lower altitudes and cause high precipitations (Kantarc1 1995). The headland (Yoroz) between the Canik-Giresun Mountains and Trabzon Mountains sites decreases the precipitation falling to the Trabzon Mountains site. This topography is a natural barrier to the moisture-bearing dominant west and north winds. Since the headlands located in the coastal region block the west winds, the eastern part of the headlands receives less precipitation than western part. It is reported that the coastline angles are an effective factor in the precipitation of the eastern and western parts of headlands (Eriş, 2011). The choice of western direction at the coastline angle is based on the dominant wind direction in the study area. If the coastline angle is less than 90 degrees, the measurement point is blocked from the west and north winds and receives less precipitation than the areas with an angle greater than 90 degrees (Eriş, 2011). Accordingly, among the measurement stations on the coast of Trabzon, the coastline angles of Vakfikebir and Of were determined to be above $90^{\circ}$ while the coastline angles of Akçaabat, Trabzon, Arsin, Araklı and Sürmene were determined to be below $90^{\circ}$. Even in this study, Vakfikebir region was evaluated within the boundaries of Canik-Giresun Mountains sites while Of and Çaykara and Uzungöl regions at the same vertical position were evaluated in Rize-Kaçkar Mountains site.

Orographic precipitations are mostly observed in these sites that receive the influence of the sea. Orographic precipitation takes place in a mountain range at middle latitudes the axis of which is perpendicular to the wind direction. In the climatological average, the windward side of the mountain range receives more precipitation from the non-windward side reflected by sharp transitions in climate, flora and fauna, known as rain shadow (Roe, 2005). Orographic precipitation is at the center of the interaction between the field surface and the atmosphere. It is not only important for the management of natural ecosystems and drinking water resources but also has important subcomponents for the other physical components of the world system. For instance, on short time scales, natural hazards such as sudden floods, landslides and avalanches are affected by precipitation in mountainous regions (e.g., Caracena et al. 1979, Caine 1980, Conway \& Raymond 1993). Finally, for millions of years, orographic precipitation models control the surfacing of rocks moving to finalize erosion and ultimately mountain ranges (e.g., Beaumont et al. 1992, Willett 1999, Montgomery et al. 2001, Reiners et al. 2003, Anders et al. 2004a, Roe et al. 2004).

\section{Relationships between spatial factors, climate and species distributions in forest sites}

The Eastern Black Sea region is a geographical area where there are very significant ecological differences between its slopes facing the sea by the effect of steep highland. The forests of the Eastern Black Sea are the forests that strictly reflect the effects of precipitation, one of climate factors, and the altitude and aspect, physiographic factors. This section includes the areas with the highest precipitation values (Rize $2441 \mathrm{~mm}$ ) of Turkey (Ardel et al. 1969, Erinç 1969). While the maximum level of diversity was reached in the vegetation stages, high slope and aspect differences increased the ecotype richness of Eastern Black Sea forests (Efe and Sönmez, 2006). The location of the mountains against the winds coming over the sea causes significant precipitation differences while altitude causes significant 
temperature differences. The change of precipitation and temperature according to the earth's shape has enabled the emergence of significant ecological differences. The presence of a high mountain or mountain ranges located in the climate region enables the formation of one or more separate environments in the vertical direction. The altitude, direction of extension of mountains, direction of the slope, ruggedness and slope conditions that constitute the properties of the earth surface, and some surface features affect the distribution of climate elements such as temperature, precipitation, fog and wind, which plays a significant role on the spread of plants and the biomass efficiency (Atalay, 2014). In the correlation analyses, it was stated that the precipitation decreased in site regions due to the altitude and distance from the sea in the site under the influence of the sea, but the number of foggy days increased. When altitude and distance from the sea factors are evaluated together, the increase in the number of foggy days against the decrease in precipitation gives us information about the moisture that can maintain the life of high mountain forests despite being far away from the coast.

Fog is considered as an important ecological factor in mountain cloud forests in the world (Cavelier and Goldstein 1989, Schemenauer and Cereceda 1994, Walmsley et al. 1996, Bruijnzeel 2001). The fog droplets on the vegetation cover can serve as an additional water source supplementing the amount of precipitation (Bruijnzeel and Proctor 1995, Hutley et al. 1997, Chang et al. 2002, Gutierrez et al. 2008); however, its contribution to groundwater is limited (Eugster 2007, Ritter et al. 2008). In several previous studies, complete tree transpiration was measured in the cloud forests (Hafkenscheid 1994, Santiago et al. 2000, Motzer et al. 2005). Hutley et al. (1997) reported a 40\% decrease in the tree transpiration rate of foggy conditions on a single tree in a small forest land in the southeastern Queensland. Johnson and Smith (2008), when Rhododendron catawbiense Michx and Abies fraser (Pursh) Poiret seedlings were compared with open days, reported an estimated reduction in the leaf transpiration of 83-95\% in a 6-day study in the southern Appalachian Mountains.

It has been reported that altitude plays an important role in determining the amount of fog. Provided that there is sufficient moisture support (Zangvil, 1996), it has been reported that altitude may lead to an increase in fog precipitation as a result of low temperatures in higher fields (Levi, 1967; Oke, 1978). The distance from the sea factor was also considered to be a critical factor for dew and fog precipitations. Precipitation is expected to decrease as going away from the sea (Zangvil, 1996). Thus, as going away from the sea, both factors, altitude and distance, may contribute to increasing or decreasing the dew and fog amounts by their geographical locations. The size, shape and structure of the trees that prevent the fog droplets and wind velocity are effective on the amount of fog water that contributes to the ecological system (Parsons, 1960). Furthermore, Went (1955) determined that the leaf surfaces of coniferous species were much more effective on the interception of fog water.

\section{Conclusion}

In this study, the relationships between the spatial factors affecting the distribution of tree species in the sub-regional sites which are under the influence of the sea in the Eastern Black Sea Region and climate variables were revealed.

In many parts of the world, mountains are open to the effects of a rapidly changing climate and are extreme places for early detection and analysis of the signals of climate change and their effects on hydrological, ecological and social systems. Furthermore, probably the most significant effect of climate change in mountain ecosystems will be seen in the spatial size of forest ecosystems and in upper forest boundaries. Therefore, when tree species at $3^{\text {rd }}$ altitude step (above $2000 \mathrm{~m}$ ) where the distance from the sea and altitude are extreme are taken into account, Scots pine, Oriental Spruce and Fir are spread in Canik-Giresun Mountains, Oriental Spruce and Scots pine are spread in Trabzon Mountains, and Oriental Spruce, Oriental Beech and Fir are spread in Rize-Kaçkar Mountains. Despite the decreasing amount of precipitation along with the increase in altitude and distance from the sea, the 
fog cloud in high mountainous areas plays an important ecological role in the conservation and distribution of these species.

\section{References}

Anderson-Teixeira, K.J., Miller, A.D., Mohan, J. E., Hudiburg, T. W., Duval, B. D., \& DeLucia, E. H. (2013). Altered dynamics of forest recovery under a changing climate. Global change biology, 19(7), 2001-2021.

Ardel, A., Kurter, A., Dönmez, Y. (1969). Climatolgy Exercise. İstanbul University Publication, İstanbul (in Turkish).

Arnbjerg-Nielsen, K., Willems, P., Olsson, J., Beecham, S., Pathirana, A., Gregersen, I. B., Madsen, H. \& Nguyen, V.T.V. (2013). Impacts of climate change on rainfall extremes and urban drainage systems: a review. Water Science and Technology, 68(1), 16.

Atalay, İ., Tetik, M., Yılmaz, Ö. (1985). Ecosystems of North Eastern Anatolia, Ege Coğrafya Dergisi, Cilt 3, Say1 1, İzmir, pp 16-56.

Atalay, İ., Efe, R., Öztürk, M. (2014). Ecology and classification of forests in Turkey, Procedia-Social and Behavioral Sciences 120: $788-805$.

Atalay, İ. (2014). Ecoregions of Turkey. Bornova - İzmir (in Turkish).

Apaydin, H., Anli, A.S., Ozturk, F. (2011). Evaluation of topographical and geographical effects on some climatic parameters in the Central Anatolia Region of Turkey. Int J Climatol 31: 1264-1279. doi: 10.1002/joc.2154.

Beniston, M. (2005). Mountain Climates and Climatic Change: An Overview of Processes Focusing on the European Alps. Pure Appl Geophys 162: 1587-1606. doi: 10.1007/s00024 005-2684-9.

Becker, A., Bugmann, H. (1997). Predicting Global Change Impacts on Mountain Hydrology and Ecology: Integrated Catchment Hydrology/Altitudinal Gradient Studies IGBP Report 43, Stockholm.

Beaumont, C., Fullsack, P., Hamilton, J. (1992). Erosional control of active compressional orogens. In: McClay KR (ed) Thrust Tectonics, Springer, Dordrecht, pp 1-18.

Bonan, G.B., Pollard, D., Thompson, S.L. (1992). Effects of boreal forest vegetation on global climate. Nature 359: 716-718.

Bruijnzeel, L.A., Proctor, J. (1995). Hydrology and biochemistry of tropical montane cloud forests: What do we really know? In Tropical Montane Cloud Forests. In Hamilton LS, Juvik JO, Scatena FN(eds) Ecological Studies, Vol. 110. Springer-Verlag, New York, pp 38-78.

Bruijnzeel, L.A. (2001). Hydrology of tropical montane cloud forests: a reassessment. Land Use Water Res 1:1.11.18 .

Caine, N. (1980). The rainfall intensity: duration controls on shallow landslides and debris flows. Geogr Ann Ser A 62:23-27.

Caracena, F., Maddox, R.A, Hoxit, L.R., Chappell, C.F. (1979). Mesoanalysis of the Big Thompson storm. Monthly Weather Review 107(1):1-17.

Carrer, M., Urbinati, C. (2004). Age-dependent tree-ring growth response to climate in Larix decidua and Pinus cembra. Ecology 85: 730-740.

Carrer, M., Urbinati, C. (2006). Long-term change in the sensitivity of tree-ring growth to climate forcing in Larix decidua. New Phytologist 170, 861-872.

Cavelier, J., Goldstein, G. (1989). Mist and fog interception in elfin cloud forests in Colombia and Venezuela. J Trop Ecol 5:309-322. 
Chang, S.C., Lai, .IL., Wu, J.T. (2002). Estimation of fog deposition on epiphytic bryophytes in a subtropical montane forest ecosystem in northeastern Taiwan. Atmos Res 64: 159-167.

Conway, H., Raymond, C.F. (1993). Snow stability during rain. J Glaciol 39:635-42.

Çiçek, İ., Gürgen, G., Tunçel, H., Doğu, A.F. (2003). Glasıcal morphology of Eastern Black Sea mountains. The symposium of first international studies of geography (The mountainous areas of caucasus and anatolia on pleistocene and today) 09- 13 Haziran 2003, Van (in Turkish).

Daly, C., Neilson, R. P., Phillips, D. L. (1994). A statistical-topographic model for mapping climatological precipitation over mountainous terrain. Journal of Applied Meteorology 33 (2): 140-158.

Davis, P.H. (1971). Distribution patterns in Anatolia with particular reference to endemism, Plant Life of South West Asia. In: Davis PH, Harper PC, Hedge IC (ed), Published by The Botanical Society of Edinburgh, Edinburgh, pp $15-28$.

Efe, R., Sönmez, S. (2006). The regional distribution of the forest vegetation according to the ecological and floristic properties in Turkey. IV. National Geography Symposium (Regional Differences in Turkey in the EU Process), 25-26 May 2006, Ankara (İnTurkish)

Ehrlén, J., \& Morris, W. F. (2015). Predicting changes in the distribution and abundance of species under environmental change. Ecology Letters, 18(3), 303-314.

Erinç, S. (1969). Climatology and methods, İstanbul University Publication, İstanbul (in Turkish).

Eriş, E. (2011). Determinatıon of spatial distrıbution of precipitation on poorly gauged coastal regions, Istanbul Technical University, Department of Civil Engineering, PhD Thesis, Istanbul.

Espinoza, J. C., Chavez, S., Ronchail, J., Junquas, C., Takahashi, K. \& Lavado, W. (2015). Rainfall hotspots over the southern tropical Andes: Spatial distribution, rainfall intensity, and relations with large-scale atmospheric circulation. Water Resources Research, 51(5), 3459-3475.

Eugster, W. (2007) The relevance of fog for the vegetation: is it the water or the nutrients that matter? In Proc. Fourth International Conference on Fog, Fog Collection and Dew. In Biggs A, Cereceda P (eds). La Serena, Chile, pp 359-362.

Fisher, R.A, Williams M., Da Costa AL., Malhi, Y., Da, Costa, RF., Almeida, S., Meir, P. (2007). The response of an Eastern Amazonian rain forest to drought stress: Results and modelling analyses from a throughfall exclusion experiment. Global Change Biology 13: 2361-2378.

Funnell, D., Parish, R. (2001). Mountain environments and communities. Routledge physical environment series, London and New York.

GDF (2008). Republic of Turkey, General Directorate of Forestry, Trabzon Regional Directorate of Forestry for the years 1984 - 2008 management data, Trabzon.

GDF (2013a). Republic of Turkey, General Directorate of Forestry, Artvin Regional Directorate of Forestry for the years 2005 - 2013 management data, Artvin.

GDF (2013b). Republic of Turkey, General Directorate of Forestry, Giresun Regional Directorate of Forestry for the years 2008 - 2013 management data, Giresun.

Goulden, M.L., Wofsy, S.C., Harden, J.W. (1998). Sensitivity of boreal forest carbon balance to soil thaw. Science 279:214-217.

Gutie'rrez, A.G., Barbosa, O., Christie, D.A., Del-Val, E.K, Ewing, H.A., Jones, C.G., Marquet P.A., Weathers, K.C., Armesto, J.J. (2008). Regeneration patterns and persistence of the fog dependent Fray Jorge forest in semiarid Chile during the past two centuries. Global Change Biol 14:161-176. 
Hafkenscheid, R.L. (1994). Hydrological observations in rain forests of contrasting stature on Gunung Rakata (Krakatau), Indonesia, with special reference to the 'Massenerhebung' effect. M.Sc. Thesis. Vrije Universiteit, Amsterdam, The Netherlands.

Hutley, L.B., Doley, D., Yates, D.J., Boonsaner, A. (1997). Water balance of an Australian subtropical rainforest at altitude: the ecological and physiological significance of intercepted cloud and fog. Aust J Bot 45:311-329.

Johnson, D.M., Smith, W.K. (2008). Cloud immersion alters microclimate, photosynthesis and water relations in Rhododendron catawbiense and Abies fraseri seedlings in the southern Appalachian Mountains, USA. Tree Physiol 28:385-392.

Kantarc1, M.D. (1982). Relations between the distribution of natural tree and shrub species and characteristics of regional site in the Mediterranean Region. İstanbul University Publication no: 3054, İstanbul (in Turkish).

Kantarc1, M.D. (1995). Regional ecological units in the Eastern Black Sea Region.In: I. National Black Sea Forestry Congress, Karadeniz Technical University, Proceedings Vol 33 Trabzon, 23-25 October 1995 (in Turkish).

Levi, M. (1967). Fog in Israel. Isr J Earth Sci. 16, 7-21.

Lynch, A.H., Bonan, G.B., Chapin, F.S., Wu, W. (1999). Impact of tundra ecosystems on the surface energy budget and climate of Alaska. Journal of Geophysical Research 104(D6): 6647-6660.

MacArthur, R.H. (1972). Geographical ecology: patterns in the distribution of species. Published by Princeton University Press 41, William Street, Princeton, New Jersey.

Marquinez, J., Lastra, J., Garcia, P. (2003). Estimation models for precipitation in mountainous regions: the use of GIS and multivariate analysis. Journal of Hydrology 270: 1-11.

Montgomery, D.R., Balco, G., Willett, S.D. (2001). Climate, tectonics, and the morphology of the Andes. Geology 29:579-82.

Motzer, T., Munz, N., Küppers, M., Schmitt, D., Anhuf, D. (2005). Stomatal conductance, transpiration and sap flow of tropical montane rain forest trees in the southern Ecuadorian Andes. Tree Physiol 25:1283-1293.

Naoum, S., Tsanis, I. K. (2004.) Orographic precipitation modeling with multiple linear regression. Journal of Hydrologic Engineering, 9 (2): 73-102.

Oke, T.R. (1978). Boundary Layer Climates. Wiley, New York, 372 pp.

Park, J. I., Singh, V.P. (1996). Temporal and spatial characteristics of rainfall in the Nam River dam basin of Korea. Hydrological Processes 10: 1155-1171.

Parsons, J.J. (1960). “Fog drip" from coast stratus, with special reference to California. Weather 15, 58-62.

Pettorelli, N., Vik, J..O, Mysterud, A., Gaillard, J.M., Tucker ,C.J., Stenseth, N.C. (2005). Using the satellitederived NDVI to assess ecological responses to environmental change. Trends in Ecology \& Evolution 20:503510.

Reiners, P.W., Ehlers, T.A., Mitchell, S.G., Montgomery, D.R. (2003). Coupled spatial variations in precipitation and long-term erosion rates across the Washington Cascades. Nature 426:645-47.

Renard, S.M., Mclntire, E.J.B., Fajardo, A. (2016) Winter conditions - not summer temperature - influence establishment of seedlings at white spruce alpine treeline in Eastern Quebec. Journal of Vegetation Science 27: 29-39.

Ritter, A., Regalado, C.M., Aschan, G. (2008). Fog water collection in a subtropical elfin laurel forest of the Garajonay National Park (Canary Islands): a combined approach using artificial fog catchers and a physically based model. J. Hydrometeorol 9:920-935.

Roe, G. H. (2005). Orographic precipitation. Annu Rev Earth Planet Sci 33: 645-671. 
Santiago, L.S., Goldstein, G., Meinzer, F.C., Fowns, J.H., Mueller-Dombois, D. (2000). Transpiration and forest structure in relation to soil waterlogging in a Hawaiian montane cloud forest. Tree Physiol 20:673-681.

Scott, R.C. (2004). Global climates. In Geography Basics. In Sumner R (ed) Salem Press. New Jersey, pp 106114.

Schemenauer, R.S., Cereceda, P. (1994). The role of wind in rainwater catchment and fog collection. Water Intl 19:70-76.

Sevruk, B. (1997). Regional dependency of precipitation-altitude relationship in the Swiss Alps. In Climatic change at high elevation sites, Springer, Dordrecht, pp 123-137).

TSMS (2016). Turkish State Meteorological Service, Meteorological data processing department, Ankara.

Walmsley, J.L., Schemenauer, R., Bridgman, H.A. (1996). A method for estimating the hydrologic input from fog in mountainous terrain. J Appl Meteorol 35:2237-2249.

Went, F.W. (1955). Fog, mist, dew, and other sources of water. In: Yearbook of Agriculture, US Department of Agriculture, Washington, D.C., pp. 103- 109.

Willett, S.D. (1999). Orogeny and orography: The effects of erosion on the structure of mountain belts. J Geophys Res 104 (289): 57- 81.

Yang, J., Spicer, R.A., Spicer, T.E.V., Arens, N.C., Jacques, F.M.B., Su, T., Kennedy, M.E., Herman, A.B., Steart, D.C., Srivastava, G., Mehrotra, R.C., Valdes, P.J., Mehrotra, N.C., Ahou, Z.K., Lai, J.S. (2015). Leaf form-climate relationships on the global stage: An ensemble of characters. Global Ecology and Biogeography 24(10): 11131125 .

Zangvil, A. (1996). Six years of dew observation in the Negev Desert, Israel. J Arid Environ 32, 361-372.

Submitted: 30.06.2018

Accepted: 27.10.2018 